\title{
АНАЛІЗ ТЕКСТОВОЇ ІНФОРМАЦІЇ НА УРОКАХ ЛІТЕРАТУРНОГО ЧИТАННЯ
}

\author{
Фурман О. Ф. \\ кандидат філологічних наук, \\ дочент кафедри педагогіки та методик навчання \\ КЗВО «Хортиџька національна навчально-реабілітаційна академія» \\ Запорізької обласної ради \\ вул. Наукового містечка, 59, Запоріжжя, Украӥна \\ orcid.org/0000-0003-4353-6166 \\ olgafurman2407@gmail.com
}

\begin{abstract}
Ключові слова: комунікація, аналіз художнього твору, художнє сприйняття, змістовно-фактуальна інформація, змістовноконцеептуальна інформація, змістовно-підтекстова інформація, комунікативний підхід, читацька компетентність, читацька грамотність.
\end{abstract}

У статті розкрито особливості аналізу змістовно-фактуальної, змістовноконцептуальної та змістовно-підтекстової художньої інформації на уроках літературного читання у початковій школі, наведено приклади аналізу літературних творів.

Установлено, що змістовно-фактуальна інформація розгортається в часі - реальному або створеному письменником, завжди виражається словом. Вона виявляється під час аналізу через репродуктивні запитання за змістом тексту (що? де? коли? куди? як? тощо). Такий вид інформації тексту є посильним для сприймання дітьми молодшого шкільного віку. Змістовно-концептуальна інформація літературного тексту передає авторське ставлення до подій, задум автора, це розуміння читачем причиново-наслідкових зв'язків. Здобуваючи іï зі змісту твору, читач творчо переосмислює прочитане, спираючись на свій життєвий досвід. Змістовно-концептуальна інформація може по-різному визначатися, тлумачитися читачами. Учитель/учителька допомагає їі визначити через причинно-наслідкові запитання (чому?) чи на етапі рефлексії, з'ясувавши, що хотів сказати своїм твором автор, чому навчити.

Визначено, що змістовно-підтекстова інформація - це прихована інформація, вона «читається» здебільшого через засоби вторинної номінації (метафора, метонімія, словотворчі засоби, синтаксичні конструкції тощо), через художні деталі, через опис зовнішності, подій, уживання фразеологічних сполучень тощо. Появу засобів вторинної номінації пояснюють асоціативним характером людського мислення. Через аналіз мови тексту визначають імпліцитний сенс інформації твору, авторський стиль письменника. Шляхом аналізу забезпечуємо розуміння авторського задуму твору та формуємо в учнів власне ставлення до прочитаного, не нав'язуючи своєї думки через діалог із ними.

У статті проаналізовано особливості сприймання художньої інформації як складової частини читацької компетентності. Висвітлено особливості комунікативного підходу в навчально-виховному процесі, його вплив на зміну підходів до аналізу літературного тексту, його інформації, осмислення ролі художньої літератури в розвитку особистості. 


\title{
AN ANALYSIS OF TEXT INFORMATION IN LITERARY READING LESSONS
}

\author{
Furman O. F. \\ Candidate of Philology Sciences, \\ Associate Professor at the Department of Pedagogy and Teaching Methods \\ Municipal Institution of Higher Education «Khortytsia National Educational and Rehabilitational \\ Academy» of Zaporizhzhia Regional Council \\ Naukove mistechko str., 59, Zaporizhzhia, Ukraine \\ orcid.org/0000-0003-4353-6166 \\ olgafurman2407@gmail.com
}

Key words: communication, analysis of imaginative writing work, artistic perception, meaningful factual information, content-conceptual information, content-subtext information, communicative approach, reader competence, reader literacy.
The article reveals the peculiarities of analyzing meaningful factual, contentconceptual and content-subtext of artistic information in the lessons of literary reading in elementary school, an example of the analysis of the literary work is given.

It has been established that meaningful information that unfolds in real time or in time created by the writer, is always expressed by the word. It is detected when analyzing through reproductive questions on the content of the text (what? Where? When? Where? How?, Etc.). This type of information from the text is manageable for the perception of children of elementary school age. The meaningful-conceptual information of the literary text transmits the author's attitude to the events, the author's intent, this is an understanding by the reader of causal relationships. By obtaining it from the content of the writing, the reader creatively rethinks reading, relying on his/her life experience. The meaningful-conceptual information can be determined differently, to be construed by readers. A teacher helps to determine it due to causal consequential question (why?) Or at the stage of reflection, finding out what the writer wanted to tell by his/her writing, what to teach us. It is determined that content-subtext information is the hidden information, it is "read", mostly through means of secondary nomination (metaphor, metonymy, word-formation means, syntactic structures, etc.), through artistic parts, through the description of appearance, events, use of phraseological phrases, etc. The emergence of means of secondary nomination is explained by an associative nature of human thinking. The implicit meaning of the product of the writing work determine through the analysis of the language of the text , the author's style of the writer. By analysis, we provide an understanding of the writer's intention of the writing work and we form student's own attitude to the reading, not imposing our opinion through the dialogue with them.

The article analyzes the peculiarities of the perception of information of imaginative writing as a component of reader competence. It was illuminated the peculiarities of the communicative approach in the educational process, its influence on changing approaches to the analysis of literary text, its information, comprehension of the role of imaginative writing in the development of personality.
Постановка проблеми. У сучасній вітчизняній літературі ведеться постійний науковий пошук якісного оновлення методологічних і філософських засад шкільного початкового навчання. Це пов'язано 3 активним входженням України до світового культурного простору, який висуває вимоги подальшої демократизації та гуманізації освіти, зміну іiі філософії. Це призводить до пере- гляду методологічних основ педагогіки та освіти у цілому. Для західних країн ці цінності стали базовими в їх цивілізаційних культурах, зокрема в освіті. В Україні наслідком таких процесів $€$ реформа НУШ.

Методологічною основою сучасних педагогічних теорій є комунікативний підхід в освітньому процесі (педагогіка дитиноцентризму, співробіт- 
ництва, гуманістична педагогіка, педагогіка толерантності, особистісно зорієнтоване навчання та виховання, суб'єкт-суб'єктний підхід). Комунікативні навички важливі для особистісного розвитку та суспільства у цілому, вони актуалізують такі цінності, як духовність, діалог, любов, дружба, свобода, довіра, співробітництво, відповідальність, взаємодія, співробітництво, співтворчість, саморозвиток, самонавчання тощо. На нашу думку, саме таких духовних категорій потребує сучасна людина, позаяк вони зможуть зберегти іï від саморуйнування. Технологічною основою комунікативного підходу в навчально-виховному процесі $\epsilon$ створення ефективної комунікації (взаємодії) 3 метою успішного розв'язання освітніх завдань [1].

Становлення комунікативної парадигми в освіті сприяло перегляду лінгвометодичних підходів до проведення уроків літературного читання, появі нових стратегій літературного читання в початковій школі, зокрема підходів до аналізу літературного тексту, сприймання інформації, більш поглибленому осмисленню ролі художньої літератури в розвитку особистості, появі нових експертних оцінок укладання підручників у цілому та 3 літературного читання зокрема тощо.

Сучасні суспільні тенденції (прогрес інформаційних технологій, зміни в культурних традиціях української сім’і, соціуму в цілому) безпосередньо й опосередковано впливають на дитину-читача (як позитивно, так і негативно), що необхідно враховувати вчителеві початкових класів під час моделювання уроків літературного читання, вибору стратегій аналізу тексту. Батьків, які читають своїм дітям книжки в дитинстві, стає, на жаль, усе менше, тому діти, подорослішавши, таку модель не наслідують, не стають умотивованими читачами. Сучасна дитина вже з дошкільного віку сприймає інформацію здебільшого з медіатекстів, переважно $з$ усних джерел (це мультиплікаційні фільми, комп'ютерні ігри, рідше - аудіотексти, наприклад казки). У процесі шкільного навчання учні молодшого шкільного вікузалучаються до підручника та художньої літератури. Навчити сприймати, аналізувати, критично оцінювати інформацію текстів різних видів - таке завдання сьогодні розв'язує вчитель під час навчального процесу.

Таким чином, на сучасному етапі розвитку українського суспільства все актуальнішою стає проблема залучення дитини до світу книги як одного 3 джерел інформації, засобу розвитку мовлення й мислення, збагачення духовного світу, формування критичного мислення, емоційного інтелекту, моральних якостей, зокрема емпатії, отримання емоційної насолоди від художнього слова, збагачення досвіду через книгу тощо. Із метою підготовки дитини до життя у соціумі назріла необхідність навчити дитину молодшого віку розуміти зміст прочитаного, осмислено читати, усвідомлювати й відтворювати інформацію. Формуванню таких навичок сприяють уроки літературного читання в початковій школі, на яких формується читацька компетентність молодшого школяра.

Державний стандарт початкової освіти орієнтує вчителя на такі загальні результати навчання здобувачів освіти щодо сприймання, аналізу, інтерпретації, критичного оцінювання інформації в текстах різних видів: сприймає текст, аналізує й інтерпретує його, збагачує естетичний та емоційно-чуттєвий досвід, оцінює текст, вибирає тексти для читання, перетворює інформацію, читає творчо.

Актуальність вивчення зазначеної теми посилює той чинник, що рамкові документи PISA акцентують увагу на тому, що в межах PISA у центрі уваги перебуває здатність учнів/студентів застосовувати знання й уміння у ситуаціях, наближених до реального життя: учні/студенти мають продемонструвати свою здатність аналізувати інформацію, аргументувати свої думки, ефективно спілкуватися, виявляючи, інтерпретуючи та розв'язуючи проблеми в різноманітних ситуаціях і контекстах. Читацька грамотність визначається як здатність учня/студента сприймати, аналізувати, використовувати й оцінювати письмовий текст задля досягнення певних цілей, розширювати свої знання й читацький потенціал, а також посилювати свою готовність брати активну участь у житті суспільства [2, с. 34]. Відповідно до цих вимог, випускники шкіл складають $3 \mathrm{HO} 3$ української мови та літератури, під час виконання якого демонструють компетентність працювати 3 інформацією тексту, глибоко аналізувати текст. Таким чином, залучати дитину до аналізу текстової інформації треба якомога раніше.

Аналіз останніх досліджень і публікацій. У науці питання аналізу різних видів текстової інформації на уроках літературного читання в початковій школі розглядалося в контексті формування читацької компетентності (I. Старагіна, В. Терещенко, А. Панченков), сприймання художнього тексту 3 погляду його читання й розуміння смислу прочитаного (О. Савченко, В. Мартиненко), сприйняття художньої мови (А. Богуш, Н. Гавриш), вивчення художніх прозових творів (О. Никифорова, О. Фльорина), сприйняття поетичних творів (Л. Беляєва, С. Жупанин, С. Крегжде) та ін. Водночас, на нашу думку, недостатньо приділено уваги врахуванню під час аналізу тексту різних типів текстової інформації на уроках літературного читання в початковій школі.

Мета статті - розкрити особливості аналізу змістовно-фактуальної, змістовно-концептуальної та змістовно-підтекстової художньої інформації на уроках літературного читання в початковій школі. 
Виклад основного матеріалу. Уроки літературного читання в початковій школі дають можливість комунікувати («комунікація» від лат. communico - робити спільним: ділитися, наділяти, обмінюватися, радитися, повідомляти, спілкуватися, брати участь) зі своїм внутрішнім світом, учителем, автором, однодумцями чи опонентами, а отже, визначати своє «Я» як рівноправного члена у соціумі, толерувати чи заперечувати думку «Іншого», але приймати іiі. Такі категорії формують цінності особистості, які не завжди осмислювалися в нашому суспільстві: свободу слова, саморозвиток, демократію, толерантність, соціалізацію. Водночас учитель/учителька може коригувати й моральні якості учнів через аналіз учинків художніх персонажів творів.

Зазначені якості особистості неможливо сформувати без перегляду методичних та літературознавчих підходів до аналізу художніх творів у початковій школі. Учитель початкових класів повинен бути теоретично й практично підготовленим до взаємодії 3 текстами різних видів, мати високий рівень літературного розвитку: розуміти поняття «текст», «інформація тексту», знати види текстів, їхні жанрові особливості, володіти системою літературознавчих понять, навичками виразного читання, мати багатий читацький досвід тощо. Формуванню професійної компетентності вчителя початкових класів працювати 3 текстовою інформацією сприяє система дисциплін у вищому навчальному закладі, чильне місце серед яких посідають методика навчання читання, лінгвістика тексту.

Відповідно до положень Програми 3 літературного читання (О.Я. Савченко), на уроках літературного читання учні/учениці оволодівають прийомами структурно-смислового й образного аналізу текстів різних видів, формування вмінь опрацьовувати художні, науково-художні тексти. Такі завдання реалізовують змістові лінії «Досліджуємо і взаємодіємо 3 текстами різних видів» та «Розвиваємо навичку читання, оволодіваємо прийомами розуміння прочитаного». Вони передбачають цілісне сприймання учнями художніх, науково-художніх текстів, їх аналіз, інтерпретацію 3 використанням літературознавчих понять (практично); формування вмінь висловлювати рефлексивні судження у зв'язку з прочитаним, критично оцінювати інформацію в текстах різних видів та використовувати іiі для збагачення особистого читацького досвіду; оволодіння, $з$ поступовим нарощуванням ступеня складності, прийомами смислового читання, застосування різних видів читання.

Художнє сприйняття розуміємо як функціональний процес літературного діалогу між автором і читачем, який об'єднує авторське світосприйняття, закодоване в тексті художнього твору, та читацьке сприйняття, зумовлене аперцепцією, асоціаціями, настановами і спрямоване на розкодування знакової системи й розуміння змістів у супроводі відчуттів та емоцій, що пробуджуються в душі реципієнта [3].

Текст передає інформацію, є носієм завершеного повідомлення, цю його властивість називають інформативністю. Тексти будь-якого стилю, жанру, типу мовлення містять інформацію: художню, наукову тощо. Для того щоб зрозуміти текст, насамперед треба сформувати у дитини технічні навички читання. Їх у початковій школі починаємо формувати 3 першого класу. Водночас уже в період навчання грамоти забезпечуємо формування смислового читання. Діти починають читати по-новому: із часом слово прочитується, осмислюється автоматично (на завершення першого класу дитина в нормі читає цілими словами), на перший план виходить розуміння змісту тексту. Таким чином, далі дитина читає, щоб навчатися, а не просто злити звуковий комплекс слова, адже сприймає велику кількість інформації на уроках математики, природознавства, мови та читання тощо. Дитина, у якої сформовано якісні ознаки читання (свідоме, виразне, правильне, швидке), досягає кращих результатів у навчанні, $\epsilon$ більш успішною. Читання - це й процес, від якого можна отримати задоволення (емоції, почуття), насамперед це стосується художньої літератури.

В основу взаємодії зі змістом тексту на уроках літературного читання, інакше - художнього сприймання, покладено усвідомлення учнями фактичної, концептуальної, підтекстової інформації (теорія I.P. Гальперіна). Програма орієнтує вчителя на те, що таке вміння формується за допомоги вчителя без уведення термінів.

Змістовно-фактуальна інформація розгортається в часі - реальному або створеному письменником, завжди виражається словом. Вона виявляється під час аналізу через репродуктивні запитання за змістом тексту (що? де? коли? куди? як? тощо). Такий вид інформації тексту є посильним для сприймання дітьми, оскільки передбачає репродукування. Так, опрацьовуючи оповідання Галини Ткачук «Гойдалка під кленом», 3'ясовуємо, де відбуваються події, якою розвагою захоплюється дівчинка, що бачить Ніна під час гойдання, 3 ким товаришує, які квіти посадив дід Марка тощо. Цей тип інформації здебільшого передається через прямі значення слів. Це те, що автор не приховує, як розгортає зміст тексту.

Змістовно-концептуальна інформація передає авторське ставлення до подій у тексті, задум автора, це розуміння читачем причинно-наслідкових зв'язків. Здобуваючи таку інформацію зі змісту твору, читач творчо переосмислює прочитане, спираючись на свій життєвий дос- 
від. Змістовно-концептуальна інформація може по-різному визначатися, тлумачитися читачами. Учитель/учителька допомагає іiі визначити через причинно-наслідкові запитання (чому?) чи на етапі рефлексії, з'ясувавши, що хотів сказати своїм твором автор, чому навчити. Думки читачів у визначенні змістовно-концептуальної інформації можуть розходитися, не збігатися, вони творчо переосмислені ними. Важливо зрозуміти авторську позицію, його задум - заради чого створив автор текст, чому хотів навчити, що зобразити, подискутувати 3 автором. Так, з'ясовуємо, чому Ніна розтоптала квіти, для чого Марків дід висаджував квіти між деревами на майданчику, як автор ставиться до вчинку дівчинки, підтверджуємо думки словами $з$ тексту (Галина Ткачук «Гойдалка під кленом»).

Змістовно-підтекстова інформація - це прихована інформація, вона «читається» здебільшого через засоби вторинної номінації (метафора, метонімія, словотворчі засоби, синтаксичні конструкції тощо), через художні деталі, через опис зовнішності, подій, уживання фразеологічних сполучень тощо. Появу засобів вторинної номінації пояснюють асоціативним характером людського мислення. Через аналіз мови тексту визначають імпліцитний сенс інформації твору, авторський стиль письменника. Учитель (учителька), володіючи прийомами аналізу художніх засобів твору, допомагає школярам (школяркам) розуміти їхню роль у тексті. Важливим прийомом роботи під час аналізу художнього твору в початковій школі $\epsilon$ використання елементів лінгвістичного аналізу мовної тканини тексту.

На нашу думку, розуміти підтекст тексту - це найцікавіший етап роботи над текстом. Досліджуємо, доводимо словами 3 тексту, якого віку дівчинка Ніна (про це прямо не сказано в тексті), чому Ніна крадеться до кімнати батьків (іiі мучить сумління, аналізуємо смисловий відтінок дієслова), як ставляться батьки до дитини після іiі вчинку, якою була сім'я (доведіть словами 3 тексту), як характеризує дітей той факт, що діти гойдаються разом, чи прямо про це говорить автор; за допомогою яких слів передається політ дитини на гойдалці у височину, виберіть дієслова, які передають цей політ; що спільного між зачином і кінцівкою тексту; що робив Марків дід на початку й у кінці твору, як він змінив своє ставлення до дівчинки. Для розуміння внутрішнього психологічного конфлікту Ніни підказуємо дітям звернути увагу, як змінюється психологічний стан дівчинки, допомагаємо розгадати емоції, задіявши мову тексту. Мовна гра - (дельфіній (назва рослини) - дельфін) теж важливий прийом створення образу дитини, який дає нам змогу проникнути в іiі уяву, яка оживлює реальний світ, робить його казковим. Світ природи для Ніни - живий, якому можна завдати болю.

Опрацьовуючи згадане оповідання, уміщене в хрестоматії сучасної дитячої літератури, діти разом 3 учителем можуть дійти висновку: кожен має право на помилку, важливо своїми переживаннями ділитися 3 батьками (або дорослими, яким ви довіряєте), які є друзями дитини. Рідні завжди допоможуть, розрадять. Важливо, щоб таку сучасну проблему співжиття дитини й дорослого, яка не прочитується, а домислюється у творі, побачили, осмислили учні під час аналізу. Складання пам'ятки «Якщо зробив помилку...» може стати проєктом - підсумком роботи над текстом.

Визначають три рівні сприймання тексту: на першому учень (учениця) усвідомлює фактуальну інформацію, на другому - приховану (підтекст), на третьому читач естетично сприймає твір мистецтва (розглядаємо літературу як мистецтво слова). Майстерність аналізу текстової інформації вчителем полягає у тому, щоб захопити молодшого читача мовною тканиною тексту, образами, злитися 3 ними, проникнути в художній текст. Шляхом аналізу забезпечуємо розуміння авторського задуму твору та формуємо в учнів власне ставлення до прочитаного, не нав'язуючи своєї думки через діалог із ними. Діалогізація уроків літературного читання не є абсолютно новим прийомом моделювання уроків літературного читання. Однак змінився сам підхід до аналізу авторських текстів - він безідеологічний, учні висловлюють своє розуміння подій, образів, проблем у тексті тощо.

Отримати задоволення від читання, зацікавити змістом, зрозуміти підтекст - цьому сприяє якісний аналіз тексту на уроках літературного читання. Таке естетичне задоволення поліпшує розуміння інформації, умотивовує до читання, збагачує мовлення (багаті на слова багатіють, а бідні на слова бідніють - ефект Метью). Літературний текст списаний із життя, уяви письменника. Розуміти інформацію інших текстів у реальному житті (усних і писемних) - така основна мета цієї роботи.

Висновки та перспективи досліджень. Проаналізоване дає підстави стверджувати, що процес сприймання літературного твору є логічно виваженим, упорядкованим відповідно до різних типів інформації, що містить текст. Учитель початкових класів під час структурно-смислового й образного аналізу повинен ураховувати ці аспекти, піддавати аналізові всі рівні інформації. Глибокий аналіз художньої інформації створює запал, заохочує учнів читати/перечитувати текст, зосереджує увагу, позбавляє байдужості до художнього слова, розвиває дитину мовленнєво й інтелектуально. Уміння аналізувати інформацію - подальша підготовка до життя молодшого школяра/школярки, 
важливий складник читацької компетентності, читацької грамотності. Опрацьовуючи текст твору, треба працювати не тільки над його інформацією, а й сприяти духовному розвитку дитини, відходити від авторитаризму та монологізму, сприяти діалогічній комунікації.

Перспективу дослідження вбачаємо у вивченні питання аналізу типів інформації поетичних творів.

\section{ЛІТЕРАТУРА}

1. Прищак М. Методологічний концепт комунікативного підходу в освіті та педагогіці. URL: http://conf.vntu.edu.ua/znanosv/2012/txt/pryshchak.pdf.

2. Національний звіт за результатами міжнародного дослідження якості освіти PISA-2018. URL: https://testportal.gov.ua/wp-content/uploads/2019/12/PISA 2018 Report UKR.pdf.

3. Орлова О. Сприйняття як літературознавча проблема. URL: http://dspace.pnpu.edu.ua/bitstream/ 123456789/1574/1/Orlova.pdf.

\section{REFERENCES}

1. Pryschak M.D. (2012) Metodolohichnyi kontsept komunikatyvnoho pidkhodu v osviti ta pedahohitsi [The methodological concept of communicative approach in education and pedagogy]. URL: http://conf.vntu.edu.ua/znanosv/2012/txt/pryshchak.pdf.

2. Natsionalnyi zvit za rezultatamy mizhnarodnoho doslidzhennia yakosti osvity PISA-2018 [National report on the results of the international study of the quality of education] (2020). URL: https://testportal.gov.ua/ wp-content/uploads/2019/12/PISA_2018_Report_UKR.pdf.

3. Orlova O. (2011). Spryiniattia yak literaturoznavcha problema [Perception as a literary problem]. URL: http://dspace.pnpu.edu.ua/bitstream/123456789/1574/1/Orlova.pdf. 